\title{
NOTES AND LITERATURE
}

\section{SOME RECENT ADVANCES IN VERTEBRATE PALEON- TOLOGY}

THE study of the extinct life of the globe must ever be the central and basal point for an understanding of the manner in which evolution has taken place. The ultimate appeal in the theory of descent must necessarily rest with the facts in the history of animal and plant life as it is read from the records in the rocks. Organic evolution is now so firmly established in the minds of present-day scientists that a statement of its truth is no longer needed. But it is well for us to be cautious in our statements about evolution, in not expressing more than we can prove. It is quite possible that the vertebrates come from the arachnoids as Patten contends, but the evidence on this point is wholly lacking. It is also possible, nay even probable, that the crossopterygian ganoids gave rise to the land vertebrates and even a single species of this group may have been such an ancestor, but no one knows whether they did or not and to state, as many of our recent zoological text-books have done, that such was the origin of land vertebrates, is to state what is not known. It is true that the Stegocephali may have given rise to the reptiles, indeed there is very little difference between some of the reptiles and some of the Stegocephali but the proof of the descent of all reptiles from any one or all of the groups of the Amphibia is more than any one has yet given. The birds may and possibly did arise from the reptiles but the early stages are still unknown. It is the firm belief of many that paleontological proof will be forthcoming for sustaining the ideas expressed by the theory of organic evolution but the facts as they are brought to light by the study of paleontologists do not serve to show that this is true. Smith Woodward says that connecting links or even approximate links between nearly all of the great vertebrate groups are still wanting from our large collections. It may safely be said that 99 per cent. of all the collections of fossil vertebrates in the world serve to show diversifications of various groups of animals and not to connect them in any satisfactory way. There are, to be sure, connections and 
definite ones between the smaller groups of many vertebrates but not between the larger ones. Many writers, especially writers of text-books, assume much more than they can prove, and the great majority of the modern zoological text-books are sadly behind the times in matters of paleontological knowledge and works that serve as standards and bases for the construction of more elementary texts make the most bald misstatement of facts.

The general trend of paleontological research is to round out our knowledge of the diversity and structure of many groups; the establishment of a few new groups especially of lower rank; no one save Jaekel having had the temerity to propose new groups higher than sub-classes.

Not all of the recent work in vertebrate paleontology is reviewed here. Many excellent works have been sufficiently noted elsewhere but sufficient is here given to show the tendency of thought and work among the vertebrate paleontologists; that of attention to matters of structure, occurrence, association, interpretation of matters of organization and relationship, all of which are fundamental to safe conclusions regarding the larger problems of phylogeny. It is perhaps too early to arrive at such conclusions in regard to phylogeny as we should wish to have-but paleontology is 100 years old and more!

One of the more recent publications from the press of Gustav Fischer is a volume entitled "Die Abstammungslehre," a collection of twelve essays on the descent theory in the light of recent researches. The ninth essay is one by Dr. O. Abel, in which he discusses "Die Bedeutung der fossilen Wirbelthiere für die Abstammungslehre." Dr. Abel says there were two ways in which he might discuss his subject, either by giving a short résumé of the investigations of paleontologists or by discussing the methods of paleontological investigation and the bearing of the results of these methods on the descent theory. He has chosen the latter and has discussed his subject in a masterly manner. He has divided his paper into three parts with various sub-headings and discusses a phase of paleontological methods in each division. He discusses the alleged lack of material among paleontological specimens and shows that, in a few instances at least, there is more material available for study of the forms than there is for many of the recent species. The discussion of the value of reconstructions in paleontology 
is illustrated by various reconstructions of the pterodactyls from Wagler's restoration of Pterodactylus in 1830 to Eaton's restoration of Pteranodon in 1910. Dr. Abel contends that the reconstruction of a fossil species is valuable, since it gives graphically all that is known of that form at the time the restoration is given. The fact that it may be wrong is no reason why restorations should be abandoned, since they record the progress of our knowledge of animal forms.

Dr. Abel uses as an illustration of the genetic line of descent that of the Cetacea, in which group he is an acknowledged authority. His discussion is illustrated from previous papers. The descent of the whales has been brought about in the reduction of certain structures, such as the teeth and the limbs. As an illustration of a line of descent which has operated in the way of complication of structures he cites the elephant series which has been made well known through the researches of Andrews and Osborn. The reader notes with a sigh of relief that but little attention is given to the line of descent of the horse (" das Paradepferd der Paleontologie" ).

Dr. Abel's selection of the sea turtles as an example of Dollo's law that "A structure once lost or reduced in development of a race is never regained " is timely and refreshing since it has been but little used. He gives Wieland's restorations of Archelon and bases his conclusions on Dollo's researches on the phylogeny of Dermochelys coriacea. He discusses, in the two last sections of the chapter, "Stufenreihen" and illustrates his discussion by Dollo's work on the dipnoan fishes, illustrating forms from the lower Devonian to recent and, in the last section, "Ahnenreihen" he discusses the derivation of the Sirenia and illustrates by the pelvic girdles of the sea cows from the middle Eocene to recent.

The concluding remarks show a strong desire to further the relation between paleontology and zoology "damit wir mit vereinten Kräften unserem gemeinsamen Ziele, der Aufhellung der Stammesgeschichte, entgegenschreiten." In view of the fact that paleontology has been largely in the hands of the geologists this is a relation much to be wished.

Charles W. Gilmore ${ }^{1}$ has described an interesting new form of Alligatoridæ from the "Hell Creek Beds" (Upper Cretaceous) of Montana. Only a portion of the skull was preserved for description. This has been restored into the shape of the

${ }^{1}$ Proc. U. S. Natl. Museum, 41, 297-302, 2 pls. 
modern Alligator skull. After comparison with Diplocynodon, Alligator and Bottosaurus, all members of the Alligatoridae, Gilmore has described the new alligator as Brachychamps"a montana, new genus and species: He gives as the fundamental generic character of the form

In the absence of a roof-like covering formed by the premaxillaries over the anterior part of the external nares, Brachychampsa differs from all known alligators, both recent and extinct.

Some of us may be inclined to question the validity of this character for a genus but further study will doubtless establish the form on a safe basis.

Dr. W. D. Matthew has reviewed briefly ${ }^{2}$ the ideas relative to the posture and habits of life of the great ground sloth, Megatherium, and its allies from the Pleistocene of North and South America. Under Dr. Matthew's direction there has been prepared a small group of four of these large brutes in the attitudes which have been suggested as possible by the study of their skeletal anatomy. Two genera are represented-Lestodon and Mylodon. The Lestodon skeleton is mounted in the familiar pose of the Megatherium reared against a tree trunk and one Mylodon is digging at the roots of the same tree. The writer says :

These poses illustrate the theory of the habits of the ground sloth deduced by Owen from the study of the skeleton-a model of scientific reasoning whose accuracy has never been impugned.

The same writer in a short article ${ }^{3}$ describes a recently mounted skeleton of Agriochœrus as "a tree-climbing ruminant." The history of this genus is interesting in that

its various parts have been referred to no less than three mammalian orders, the head to the artiodactyls, the fore foot to the creodonts and the hind foot to the Ancylopoda.

Dr. Matthew opens his paper with the remark that

It seems somewhat paradoxical to imagine a ruminant climbing trees. He says further:

The Agriochorus, however, while a member of the Oreodont family, and like them provided with ruminating teeth, had the limbs and feet modified in such a way as to enable it to climb trees as readily as a jaguar or other large eat.

${ }^{2}$ American Museum Journal, XI, No. 4, p. 113.

${ }^{3}$ American Museum Journal, XI, No. 5, pp. 162-163. 
No one is more entitled to a view on this subject than Dr. Matthew and even if we find it hard to accept his view of such a paradox yet it behooves us not to be too skeptical.

Dr. Bashford Dean ${ }^{4}$ has described a new "fossil aquarium" recently installed in the American Museum of Natural History. Under his direction has been executed a group of Devonian fishes,

all from a single locality (Cromarty) and a single rock layer in the Old Red Sandstone of Scotland, with the best evidences therefore, that the creatures shown really existed side by side.

The fishes shown seem to be swimming through the water as if alive. It must be a very attractive group to museum visitors.

A very interesting and extremely useful work on ichthyosaurs and plesiosaurs has been issued (1910) from the British Museum (Natural History) as "A Descriptive Catalogue of the Marine Reptiles of the Oxford Clay," Part I, compiled by Dr. Charles W. Andrews. The catalogue is largely based on the Leeds Collection which the British Museum has been acquiring for the past twenty years. The volume is issued in the usual excellent form of all the previous British Museum catalogues, the illustrative work being photogravure, zine line and lithograph, all executed with great care and attention to details.

The frontispiece is a photogravure of a nearly complete, mounted skeleton of a plesiosaur (Cryptocleidus oxoniensis), a dorsal view of which species has been used by Abel for the frontispiece to his "Paleobiologie." The introduction discusses the taxonomic characters of the ichthyosaurs and plesiosaurs, the fauna of the Oxford clay and the distribution of the vertebrates. A single species of Opthalmosaurus is discussed, and the details of its anatomy are contained in the first 76 pages of the work, illustrated by 42 text figures (including a restoration of the skeleton) and two lithographic plates. Aside from a discussion of the possible identity of Opthalmosaurus and Baptanodon of America, the writer has confined his remarks to the osteologic details.

The plesiosaurs are more abundantly represented in species than are the ichthyosaurs. There are four genera discussed in the last 120 pages of the volume, illustrated by 52 text-figures, 8 lithographic and one photogravure plate (containing three restorations of the various forms). As in the previous portion

${ }^{4}$ Amer. Mus. Journal, XI, No. 5, p. 161. 
the writer has confined himself to the discussion of the details of osteology and this will make the work doubly useful to students who will find here an unbiased statement of the facts of structure of these two interesting groups of vertebrates. The work will thus be regarded as a standard book of reference on the forms there discussed. It may be regretted by some that the author has neglected the excellent opportunity to discuss such interesting factors as hyperphalangy, hyperdactyly, phylogeny, reduction of structures due to aquatic life, but perhaps this would be out of place in a museum catalogue and we may hope to have the views of Dr. Andrews on these subjects at some other time. The second volume of the series proposes to deal with the crocodiles and pliosaurs of the Oxford clay. The work will be looked for with much interest.

In a recent paper on Edestus ${ }^{5}$ Dr. O. P. Hay discusses a recently acquired specimen of this interesting Carboniferous shark from the Des Moines Stage of Iowa, discovered in a coal mine near Lehigh some 18 years ago by a miner. The specimen shows the interesting relation of the so-called spines which have been assigned various places by various writers. The specimen seems to leave no doubt that the objects regarded hitherto as spines are in reality the mandibular and maxillary cartilages of a peculiar shark. Portions of the nasal and post-nasal cartilages are preserved and Dr. Hay indicates a depression as the olfactory pit. The cartilages are so crushed that the nature of the orbital cavities can not be determined. The maxillary cartilage is somewhat larger than the mandibular, as in the modern sharks. The paper is a very interesting contribution to the subject of Paleozoic sharks. He suggests that the forms Toxoprion, Helicoprion and Lissoprion, at present known only from detached pieces, may in time prove to have the relations exhibited by the present new species of Edestus; a relation which Dr. Eastman has claimed for some time obtained in the forms.

A new mosasaur is indicated by Charles W. Gilmore ${ }^{6}$ based on imperfect remains from the Cretaceous of Alabama. Mr. Gilmore is inclined to establish a new genus on the characteristic form of the teeth of the new form. He calls the new genus Globidens, deriving his name from the Latin globus and dens, contrary to the usual custom of employing Greek roots for generic

${ }^{5}$ Proc. U. S. Natl. Museum, 42, 31-38, pls. 1-2, April 25, 1912.

${ }^{6}$ Proc. U. S. National Museum, 41, 479-484, pls. 39-40, January 31, 1912. 
terms. The species is without doubt valid and is a very interesting one in showing a new type of tooth for the mosasaurs, wherein the tooth is a rounded ball instead of being sharp as in the majority of known mosasaurs. From its rarity one may be inclined to question the normal condition of the teeth, but all the teeth display the same characters, so Mr. Gilmore is justified in his assumptions of the distinction of the form so far as the evidence goes. The species is said to be related to Platecarpus which is the common mosasaur of Kansas; but we may question whether it is a true mosasauroid.

Mr. Maurice G. Mehl ${ }^{7}$ has described and illustrated an incomplete skull of the interesting and little known cotylosaur, Pantylus cordatus Cope, from the Permian Red Beds of Texas. The species has been given the rank of a suborder, the Pantylosauria, by Case in his monograph of the Cotylosauria. The form is, however, known only from the skull and such reference may be subject to revision. Mr. Mehl was able, from the recently acquired material, to more fully describe the dentition of this molluscfeeding animal. He illustrates his discussion by several line figures.

The history of the dinosaurs will always be an interesting topic for paleontologists. The recent contribution by Mr. Charles W. Gilmore $^{8}$ is an attempt toward the completion of the history of this group of animals, wherein he describes "The Mounted Skeletons of Camptosaurus in the United States National Museum." His discussion is illustrated by drawings and photographs with a map of one of the Como, Wyoming, quarries showing the positions of the Camptosaurus bones in the quarry. The skeletons of the two species are mounted in the attitudes of walking on all fours and the erect attitude, which was possibly characteristic of many of the Theropoda. The animals are represented as being semiplantigrade in the hind foot and semidigitigrade in the fore.

Walter Granger ${ }^{9}$ has given a few notes on the locality and manner of collection of "a new specimen of the four-toed horse" discovered "in the extreme northwestern corner of Wyoming, in the Wahsatch formation of the Big Horn Basin." Since the form had previously been known only from fragments of jaws containing teeth, the recent find is a remarkably large addition

'Journal of Geology, XX, No. 1, 21, 1912.

${ }^{8}$ Proc. U. S. Natl. Museum, 41, 687-696, pls. 55-61, February 8, 1912.

${ }^{9}$ American Museum Journal, XI, No. 3, pp. 85-88. 
to the already rich collections of the American Museum. It is to be hoped that the skeleton will be shortly described.

"A Revision of the Amphibia and Pisces of the Permian of North America with a Description of Permian Insects"' is the work of E. C. Case, Louis Hussakof and E. H. Sellards, issued as Publication No. 146 of the Carnegie Institution of Washington, on December 20, 1911. The larger part of the work, 148 pages, 51 text-figures and 25 plates, is given to the discussion of the Amphibia which constitutes Dr. Case's contribution to the volume. Ten families of Amphibia are discussed in an historical, systematic and morphological manner, the last two being given approximately equal space. The "historical" portion of the discussion consists of the history of discovery and the taxonomy of the Permian forms as viewed by various writers from Cope (1875) to Broom (1910). The chief taxonomic schemes are given, with lists of species.

The systematic section opens with a table of "Classification" which adopts the opinions of Zittel published many years ago and which, in the main, seems to represent the facts as we now know them. Dissent has already been made as to the inclusion of the Diplocaulidæ in the order Microsauria to which group of vertebrates they have not the slightest relationship. The anatomy and relationships of the group have been discussed elsewhere ${ }^{10}$ and it will only be necessary to state here that the structure, as we now know it, seems to point to a relationship of the Diplocaulidæ with the true Amphibia, $i$. e., the Branchiosauria and the Caudata. A new order, Diplocaulia, has been erected for the reception of the species of the family. It is only proper to say that Dr. Case includes the Diplocaulidæ with the Microsauria provisionally. In the morphological section Dr. Case says (p. 90) :

Jaekel's suggestion of the derivation of Diplocaulus from forms like Ceraterpeton and Diceratosaurus is very probably correct.

He gives not the slightest reason for the assumption of the correctness of this view, which, in the light of the facts, can not be regarded as other than preposterous. The derivation of Diplocaulus from such differently organized animals as Ceraterpeton and Diceratosaurus is fully as fanciful as Jaekel's suggestion to Dr. Traquair of the probable descent of Hunsrïckia "jene ältesten Fische von terrestrischen Tetrapoden abstammen."

${ }^{10}$ Journal of Morphology, XXIII, No. 1, March, 1912. 
The section on the temnospondylous Amphibia is taken up with descriptions of the osteologic characters of the various species with little or no attempt at phylogenetic conclusions. This will make the present monograph the central point, a base of supply, from which future discussions must radiate. Dr. Case's work is reviewed more in detail by Mr. Mehl in Science, September 27, 1912, p. 408.

The second volume of Dr. Case's series of monographic studies on the American Permian vertebrates was issued October 25, 1911, as Publication No. 145 of the Carnegie Institution of Washington. In this volume Dr. Case has brought together all of the important facts concerning the "Cotylosauria of North America" with many notes on foreign genera. The volume has 121 pages, 14 plates, 52 text-figures and 71 bibliographic references. As in his previous volume on the "Pelycosauria" the author has divided this volume into the following sections: "Historical Review," "Classification," "Systematic Revision," "Morphological Revision" and "Conclusion."

The reptilian order Cotylosauria of Cope at present has assigned to it by paleontologists thirty genera, distributed in ten families and placed by Dr. Case in five suborders. Each species has the original description and a "revised description" so that later workers on these Permian reptiles will have at hand ready information concerning all the Cotylosauria known up to the end of the year 1911.

The members of the group are known mostly from fragmentary remains. Only in one case, that of Diadectes phaseolinus Cope, was the author able to restore the approximate skeleton of the species. Other forms have, however, been restored, notably, Sclerosaurus from Europe by von Huene, Telerpeton from Scotland by Boulenger, Captorhinus and Seymouria from Texas by Williston and Labidosaurus from Texas by Broili and Williston. Much still remains to be determined as to the structure of nearly all the species.

The facts of most general interest are the structure of the skull of these reptiles and the description of a brain cast of Diadectes, figured on Plate 7, Figs. 2 and 3. The structure of the skull allies the group with the stegocephalous Amphibia. The former notions of the Cotylosauria allied the group with the Stegocephala. Further study, however, has convinced Dr. Case that the group is "very far from occupying the primitive position assigned to it 
by Cope." Possibly new discoveries of the appendicular skeleton will widen this gap and give us more definite ideas of the organization of what are possibly the most primitive of the known Reptilia. Similar ideas were formerly held as to the position of the mammalian order Condylarthra, but further knowledge of the anatomy of the skeleton of the body has convinced Dr. Matthew that the group has many characters which are not at all primitive and which would seem to remove the group from an ancestral position.

The Cotylosauria originated probably as early as the middle Pennsylvanic, although the evidence for this is uncertain. Two genera of reptile-like forms known from the Carboniferous of Ohio and France, Eosauravus Williston and Sauravus Thevenin, are doubtfully assigned to the order. If these are not Cotylosauria then the order is Permian. The Cotylosaurian reptiles have been found in America, Europe and Africa. There is little relationship existing between the faunas of the various continents and the place of origin of the order is uncertain, since representatives are found on both sides of the water at practically the same time geologically. This same thing is true among other fossil vertebrates, notably Eohippus, the Branchiosauria, the Microsauria, the Embolomeri, etc. The significant conclusion is reached that:

There is no single one of the Cotylosauria that can be considered as an ancestral form of the other reptiles. . . . It is impossible to derive the Diapsidan and Synapsidan types from the known Cotylosaurs.

The make-up of the work is excellent. The figures are many of them new and all are well executed. The author has drawn on published matter to the Cotylosauria and has inserted figures from Cope, Broili, Williston, Boulenger, Moodie, Thevenin, von Huene and others, for all of which proper credit is given. The photographic plates are an especial desideratum, for while it leaves the exact description of the elements somewhat uncertain to the reader, yet one feels more at ease on seeing a photograph of the material. Most of the specimens described are in Walker Museum at the University of Chicago and the American Museum of Natural History in New York City.

Roy L. Moodie.

UNIVERSITY OF KANSAS

( $T$ o be continued) 